\title{
Engaging and Motivating Students in Engineering Communication with Com- petition and Prizes
}

Katherine Golder, British Columbia Institute of Technology

Katherine Golder teaches Technical Communication for students in Electrical and Computer Engineering at the British Columbia Institute of Technology in Burnaby, BC, Canada.

Ms. Deanna Gail Levis, British Columbia Institute of Technology

Instructor, Communication Department

Ms. Darlene B Webb, British Columbia Institute of Technology

Darlene Webb teaches junior and senior technical communication courses to mechanical engineering technology students at BCIT in Burnaby, BC, Canada. 


\section{Engaging engineering students in communication through an oral presentation competition with prizes}

This work-in-progress examines an oral presentation competition for engineering students, Presentation Idol for Engineering Students (Idol). The aim of Idol is to motivate students and engage them in the process of building crucial communication skills through a fun, competitive, industry-oriented event. In a brief review of engineering communication literature and an analysis of pre- and post-Idol surveys, we attempt to elucidate what motivates engineering students to complete in Idol. This is a case study specific to Idol, so it is not meant to provide generalizable results.

\section{What is Presentation Idol?}

Idol is organized by three instructors teaching communication courses for the civil, mechanical, and electrical engineering technologies at a polytechnic institute in western Canada. The Idol competition is geared specifically for engineering students. Although Idol is organized by communication instructors, it is not part of any courses, and students are not required to participate. Instead, Idol is advertised on campus and online, and eligible students can go to the Idol website's registration page to sign up free of charge.

\section{How did Presentation Idol begin?}

In the fall of 2010, the three instructors were brainstorming ideas on how to motivate engineering students to hone their oral presentation skills and showcase their engineering talents in a fun, competitive arena, and Presentation Idol for Engineering Students was born. The first event was held in the spring of 2011, with over \$2,000 in prize money. After the success of the inaugural event, Idol was held again in May, 2012, and with industry support, the prize pool for the 2012 competition grew to over \$3,300. The next Idol competition for spring, 2013 is currently being planned. Having started as a simple idea for an extra-curricular activity, Idol is now on its way to becoming an ongoing event at the institute.

\section{How does Presentation Idol work?}

To make the event successful, the following seven steps need to be taken: (1) finding the sponsors, (2) marketing the competition, (3) registering the students, (4) planning the two events, (5) preparing refreshments and gifts, (6) voting for audience choice prizes, and (7) updating after the event.

\section{Finding Sponsors}

Finding sponsors is the most important and probably most challenging task, particularly in the first year or two. We find most sponsors by canvassing engineering companies, book publishers, and engineering departments at the institute.

2. Marketing the Competition 
Word of mouth among the students, posters displayed around the campus, and a dedicated website for Idol are the most useful marketing methods.

\section{Eligibility and Registration Process}

Students must be currently enrolled in an engineering program and have taken at least one communication course through our communication department. Registration is done online and is limited to 40 contestants. Time allotted for presentations is 6-10 minutes, with topics related to engineering, sustainability, or the environment.

\section{Planning for the Preliminary and Final Competitions}

Presentations occur in four rooms, with 8-10 presenters. The top 2 in each room move on to the championship the following week. We suggest 3 (minimum 2) judges per session and 1 moderator to introduce the speakers. For the final event, we have videographers record the 8 finalists' presentations.

\section{Preparing Refreshments, Door Prizes, and Gifts}

To make the event special, we provide gift bags and snacks for participants and judges. We also provide light refreshments for the audience, participants, judges, and moderators, and door prizes for the final event.

\section{Voting for Audience Choice Awards}

The audience choice awards represent an important part of the Idol experience for both contestants and audience members. First, second, and third place winners are selected (using paper ballots) by the audience, with votes counted quickly after the final presentation. Since prize money and other gifts for these winners are substantial, a great deal of interest is taken by all in this aspect of the competition.

\section{Post-Idol Updates}

Following the event, the website is updated with text, photos of the event highlights, and finalists' videos. Comments by participants and audience members there to support the participants are added as well. Post-Idol surveys were taken to gauge the differences in selfconfidence experienced by participants before and after the event (see Appendix C).

\section{What are the effects of the competition?}

The significance and effects of the competition have far exceeded the expectations of the organizers and the institute. The Idol event has become a touchstone for many themes the organizers consider important in their own teaching: student engagement, networking, personal growth, and industry and family involvement. The interdisciplinary focus of the event is another plus, not only for the students and instructors, but also for the institute's strategic plan. 
Although we didn't set out to do research, the event has been fertile ground. Students, industry judges, communication and engineering instructors, other instructors who teach into engineering, and the management of the institute have all become engaged in the Idol event, which has motivated our interest in researching issues around Idol.

\section{What is the main focus of this polytechnic institute?}

The institute that is home to Idol focuses primarily on preparing students for successful careers, and most often hires instructors who bring prior industry experience to their teaching positions along with their academic credentials. Industry involvement with instructors, course materials, and collaboration with student projects is common and encouraged, so students get firsthand experience with workplace standards and practices.

For students, assignments and extracurricular activities that have clear links to their future working life make their courses more meaningful to them and more practical for the workplace. For instructors, this system demands time in keeping up to date on current industry practices, contacting industry professionals, and adapting materials to be relevant to those practices. While research is done at the institute, the main focus is teaching: teaching loads are heavy, teaching assistants to help with marking are rare, and time for research is not part of our workloads. So, extracurricular events such as Idol create major logistical issues within the system.

This presentation details our findings on students' motivation and satisfaction with their oral presentations, both in required communication courses and in Idol, including a description of

- description of the structure and delivery of Idol

- literature related to the event

- research methodology

- survey results from students who have given oral presentations in "regular" communication classes and those who have participated in Idol

- students' attitudes and self-efficacy about public speaking

- factors that motivate students to participate.

\section{Literature review}

Once we saw how well-received Idol was, we put together some quick survey questions, gathered some data from students, and then went back to see where our research fit in the existing literature. We knew from the beginning that Idol could add important contributions to research into communication skills in engineering, and research on student motivation and persistence. We also recognized that Idol is a good example of faculty and student collaboration, interdisciplinary initiatives, and that it shared many of the qualities of demonstrated educational games. This review of the literature will cover these areas.

Communication in engineering 
As communication instructors, we sought to ensure that our view of communication skills as key to successful careers in engineering was more than just our bias toward our area of specialization. Fortunately, finding sources to back up that view is not challenging:

The Canadian Engineering Accreditation Board (CEAB, the Canadian version of ABET) defines communication skills as "an ability to communicate complex engineering concepts within the profession and with society at large.” For a program to be accredited, the institution must be able to demonstrate that its graduates have these skills. ${ }^{1}$ Similarly, ABET lists "an ability to communicate effectively" with the 11 major student outcomes required for an engineering program to be accredited. ${ }^{2}$

Educating the Engineer of 2020 emphasizes the importance of communication and teamwork skills. ${ }^{3}$ Articles in JEE and various ASEE conference papers and presentations all stress the importance of communication skills. ${ }^{4-7}$ The ASEE's Innovation with Impact report ${ }^{8}$ also notes the increasingly important role that communication skills play in a successful engineering career.

Student engagement and persistence in engineering programs

Until recently, a culture of student engagement outside the classroom was somewhat lacking at our institution. Students typically arrived at the institute to get an engineering credential and to get a job. However, in the two years since Idol began, this has changed: the IEEE student chapter has seen increasing enrollment (from 8 members in 2008 to 76 in 2013 ${ }^{9}$ ), a Women in Engineering club has been initiated, an Engineers Without Borders chapter has been sanctioned by EWB Canada, and an Engineering Students Society has been formed. These are all important for both program accreditation (section 3.5, 'Program environment' of the CEAB Accreditation Criteria and Procedures ${ }^{1}$ ) and student engagement. The importance of engaging students in the engineering community is also highlighted in Innovation with Impact. ${ }^{8}$ Recommendation 3 is to “continue current efforts to make engineering programs more engaging and relevant and especially expand efforts to make them more welcoming” (p. 48).

Despite heavy school workloads and part-time jobs, engineering students have demonstrated eagerness to belong to engineering-related clubs and projects. Allendorfer et al ${ }^{10}$ explore the idea that a sense of belonging is a fundamental human motivation and is directly linked to academic outcomes in higher education, including student persistence in a program. Family, clubs, and other outside communities strengthen a student's engagement with his or her studies. Rodgers et $\mathrm{al}^{11}$ found that lack of belonging was among the top three reasons for students transferring out of engineering programs at their institution. (The other two reasons were poor teaching and advising, and the difficulty of the curriculum.) Idol provides students with an opportunity to gather as members of the engineering community, share their ideas and knowledge, and foster a sense of belonging.

Interdisciplinary collaboration

The gathering facilitated by Idol includes not only students from different engineering programs but also faculty from engineering programs, faculty in the Communication Department, industry 
representatives, and the institution's management (associate deans, deans, the vice president of education, and the president). This represents a significant collaboration among these groups and demonstrates to students that the community they belong to goes beyond their peers in engineering: it is deeply connected with the institute and the professional community of engineers and technologists. As well, this demonstrates a step towards implementing Innovation with Impact's Recommendation 2 to expand collaborations and partnerships. ${ }^{2}$

\section{Educational games}

As mentioned above, we didn't look at the research on game-based learning and then decide to develop a game for our students. Instead, we wanted to find an engaging way to give our students an opportunity to show off their skills. At the same time, we wanted to debunk the stereotypes about engineering students lacking public speaking skills. Another stereotype that Idol challenges is that if you're having fun, you can’t really be learning.

As Klopfer, Osterweil, \& Salen ${ }^{12}$ note, games are often seen as “insufficiently serious.” Klopfer, Osterweil, \& Salen focus on video games, but many of the characteristics they cite as elements of games are also elements of Idol: among other things, gaming requires "players to be fluent in a series of connected literacies that are multi-modal, performative, productive, and participatory in nature.” It also requires "risk-taking, meaning creation, non-linear navigation, problem-solving, an understanding of rule structures, and an acknowledgement of agency within that structure.”

Similarly, the 2011 Horizon report ${ }^{13}$ (also focused on video games) describes "aspects of games that make them especially engaging to players of various ages and both genders.” The aspects that apply to Idol include the

- feeling of working toward a goal

- possibility of attaining spectacular success

- ability to problem-solve, collaborate with others, and socialize.

Henderson ${ }^{14}$ describes classroom games as "any activity that involves a competition, social interaction, and some form of prize or award." In addition, to having winners, ideally "even the losers of the game should feel that the experience was enjoyable.”

As will be described later, one of the elements of Idol that students found engaging was the connection to the "real world" outside of the classroom. Trybus ${ }^{15}$ argues that "we don't need more time in the classroom to learn how to think and perform in the face of real-world challenges. We need effective, interactive experiences that motivate and actively engage us in the learning process.” Idol provides students with the opportunity for these experiences. Even those who participate more passively as audience members are engaged and invested in the experience while watching their friends and classmates compete.

\section{Research framework}

As established in the foregoing literature review, the value of communication skills has been extensively researched and well covered in publications like the Journal of Engineering 
Education. However, few, if any, studies focus on whether cash prizes and a competitive environment are motivating factors for students who deliver oral presentations. We found that factors like prizes and competition motivate students to participate in oral presentations and that these factors are similar to those which motivate gamers.

Feedback from students, faculty, and management indicated that Idol was successful after its first iteration, and we were curious about why it had been so successful. Based on this feedback, we decided to investigate what factors motivated students to participate in Idol and what, if anything, was different or changed for students after delivering an oral presentation in a regular core communication class versus after having delivered at presentation at Idol. Because we had no hypothesis that we sought to prove as a result of administering the Idol event, we chose to situate our inquiry within the case study methodology:

Case study as a methodology can be used as motivation for the validity of findings emerging either from an analysis of a single case or across multiple cases....the concrete, context-dependent nature of the knowledge which case studies unearth, on which these critiques focus, however, is precisely the source of its methodological strength. Case study can therefore be particularly appropriate to address research questions concerned with the specific application of initiatives or innovations to improve or enhance learning and teaching. 16

Knowing students' motivating factors for participating in Idol will help us expand and improve the event and may help engineering and communication instructors to tap into students' motivating factors and incorporate similar activities into the undergraduate engineering experience or use such activities to strengthen academic engagement or academic performance.

\section{Research methods, results, and discussion}

To discover the motivating factors for students delivering presentations in required communication courses and to discover motivating factors for students participating in Idol, four separate surveys on students' attitudes towards public speaking were administered. Survey participants were recruited in the Fall 2011 semester for Surveys 1 and 2 (Pre- and post-Comm) and in the Spring 2012 semester for Surveys 3 (Pre-Idol) and 4 (Post-Idol).

Surveys 1 and 2: Pre- and post-Comm

Two surveys were given to engineering students at the institute from civil, mechanical, and electrical engineering disciplines in their first semester communication course. The engineering students were contacted via email by a researcher from the Learning and Teaching Centre to avoid having the surveys sent by the students' instructors for the communication class. Students completed the surveys online outside of regular communication classes. No incentive gifts or extra credit whatsoever was allowed for completing the survey. Students were assured that their participation in the survey was completely voluntary and that their survey responses would be confidential. 
At the institute, engineering students from all disciplines, pursuing either the two-year diploma or four-year degree program, are required to take communication courses. Delivering oral presentations is a key component of these courses. One of the communication instructors uses the Norback \& Utschig's Presentation Scoring System (Appendix A). ${ }^{17}$ The other instructors evaluate the presentation on criteria similar to those outlined in Norback and Utschig's rubric.

These disciplines were chosen for pre-Comm and post-Comm surveys because they represent the majority of engineering students at the institute. Surveying these students was intended to provide a sense of the general population of engineering students' attitudes towards public speaking in comparison with those students who choose to participate in Idol. In the future, we plan to expand the survey to include other engineering disciplines, such as architecture and building, chemical and environmental, and biomedical engineering students.

Surveys 1 and 2 (pre- and post-Comm) were identical, asking students about their experience with and attitudes towards giving presentations. Survey 1 was administered before the students gave presentations in their communication course (Pre-Comm). In total, 62 engineering students participated in the pre-Comm survey. Survey 2 was administered after the student presentations (Post-Comm). In total, 15 engineering students participated in the post-Comm survey. See Appendix B for the full pre- and post-Comm surveys.

\section{Survey 3: Pre- Presentation Idol}

A “Pre-Presentation Idol Registration Survey” (Appendix C) was available for students to complete when they registered to participate in Idol, and 12 registrants completed this survey. In the spring of 2012, a total of 30 students registered and 24 competed in Idol.

\section{Survey 4: Post- Presentation Idol}

"Post-Presentation Idol Survey" (Appendix C) was targeted to students who had participated in Idol. Six responses for the Post-Presentation Idol Survey were received.

The distribution of survey respondents by survey type is shown below in Table 1 .

Table 1: Distribution of survey respondents

\begin{tabular}{|l|l|l|l|l|}
\hline Engineering Major & $\begin{array}{l}\text { Pre-Comm } \\
\text { survey } \\
\mathrm{N}=62\end{array}$ & $\begin{array}{l}\text { Post-Comm } \\
\text { survey N=15 }\end{array}$ & $\begin{array}{l}\text { Pre-Presentation } \\
\text { Idol survey N=12 }\end{array}$ & $\begin{array}{l}\text { Post-Presentation } \\
\text { Idol survey N=6 }\end{array}$ \\
\hline Civil & 22 & 11 & 5 & 2 \\
\hline $\begin{array}{l}\text { Electrical \& } \\
\text { Computer }\end{array}$ & 16 & TBA & 3 & 1 \\
\hline Mechanical & 24 & 4 & 1 & 1 \\
\hline $\begin{array}{l}\text { Architectural and } \\
\text { Building Engineering }\end{array}$ & 0 & 0 & 3 & 2 \\
\hline
\end{tabular}

In this table, no distinction is made between two-year diploma and four-year degree students. These numbers also include "undecided" students, those who are in a declared major but have 
not decided whether to pursue the four-year engineering degree at the institute. At the time of writing this paper, the Post-Comm survey results for Electrical \& Computer Engineering had not yet been received from the survey administrator.

\section{Survey results and analysis}

Each of the four survey types listed above contained questions about students' level of education, years of full-time work experience, and experience giving oral presentations based on audience size and purpose (work, school, volunteer or other). This information is presented in Appendices B through E.

In addition to the questions described above, Pre- and Post-Presentation Idol surveys contained questions about participants’ engineering discipline, length of program, gender, age, and experience giving oral presentations based on audience size, purpose (work, school, volunteer or other), and motivation for participating. The Post-Presentation Idol survey also gathered information about participants' satisfaction around the execution of the event (location, value of prizes, quality of judging, and registration procedures).

The results of these surveys are described below.

Results for Survey 1: Pre-Comm

In response to the question, “Would the competitive nature of Idol motivate you to participate?” more than three quarters of the respondents said "no."

Table 2: Response to Pre-Comm survey question "Would the competitive nature of Idol motivate you to participate?”

\begin{tabular}{|l|l|l|}
\hline Response & Count & Percent \\
\hline Yes & 5 & $21.7 \%$ \\
\hline No & 18 & $78.3 \%$ \\
\hline
\end{tabular}

These survey results may indicate that the competitive nature of Idol is not a motivating factor for most students in typical first-year communication courses.

However, students responding to the Pre-Comm survey were more likely to be motivated by the chance to win money, as indicated in Table 3 below.

Table 3: Response to Pre-Comm survey question "Would the chance of winning prize money in a competitive situation motivate you to participate in Idol?”

\begin{tabular}{|l|l|l|}
\hline Response & Count & Percent \\
\hline Yes & 15 & $65.2 \%$ \\
\hline No & 8 & $34.8 \%$ \\
\hline
\end{tabular}


These results indicate that the chance of winning prize money is a greater motivating factor for engineering students to sign up for Idol even for students in introductory communication classes.

Results for Survey 2: Post-Comm

After having given presentations in their communication classes, the students were surveyed again to see if their attitudes about public speaking and Idol had changed.

Table 4: Response to Post-Comm survey question "Would the competitive nature of Idol motivate you to participate?"

\begin{tabular}{|l|l|l|}
\hline Response & Count & Percent \\
\hline Yes & 6 & $40.0 \%$ \\
\hline No & 9 & $60.0 \%$ \\
\hline
\end{tabular}

There is an almost $20 \%$ increase in students indicating that the competitive nature of Idol is a motivating factor after having completed at least one communication course. However, the number of students indicating that the chance of winning prize money would motivate them decreased by about $5 \%$.

Table 5: Response to Post-Comm survey question "Would the chance of winning prize money motivate you to participate in Idol?”

\begin{tabular}{|l|l|l|}
\hline Response & Count & Percent \\
\hline Yes & 9 & $60.0 \%$ \\
\hline No & 6 & $40.0 \%$ \\
\hline
\end{tabular}

Results for Survey 3: Pre-Presentation Idol

As shown in Table 6 below, for the Pre-Idol survey participants, there is an increase of almost $40 \%$ in students indicating that the competitive nature of Idol is a motivating factor for signing up compared to the respondents in the pre-communication course and an increase of more than $20 \%$ compared to the post-communication survey respondents.

Table 6: Response to Pre-Idol survey question "Does the chance of presenting in a competitive situation with your peers motivate you to participate in Idol?”

\begin{tabular}{|l|l|l|}
\hline Response & Count & Percent \\
\hline Yes & 7 & $63.6 \%$ \\
\hline No & 4 & $36.4 \%$ \\
\hline
\end{tabular}

Table 7: Response to Pre-Idol survey question "Does the chance of winning prize money in a competitive situation motivate you to participate in Idol?” 


\begin{tabular}{|l|l|l|}
\hline Response & Count & Percent \\
\hline Yes & 10 & $83.3 \%$ \\
\hline No & 2 & $16.7 \%$ \\
\hline
\end{tabular}

Here the results are quite dramatic: the students who register for Idol are clearly motivated to participate because of the prize money available, an increase of almost 30\% compared with the pre-Comm survey respondents and an increase of $23.3 \%$ from the post-Comm survey respondents.

Results for Survey 4: Post-Presentation Idol

On a scale of 1 to 5, where 1 represents "not motivating at all" and 5 represents "very motivating" rate how motivating it was for you to participate in Idol knowing that a substantial amount of prize money could potentially be won.

Table 8: Response to Post-Idol survey question on motivation and prizes

\begin{tabular}{|l|l|l|}
\hline Response & Count & Percent \\
\hline 1 & 1 & $16.7 \%$ \\
\hline 2 & 0 & $0.0 \%$ \\
\hline 3 & 2 & $33.3 \%$ \\
\hline 4 & 1 & $16.7 \%$ \\
\hline 5 & 2 & $33.3 \%$ \\
\hline
\end{tabular}

Here, $50 \%$ of post-Idol survey respondents said that the potential for winning prize money was very or significantly motivating.

One of the Idol winners commented on another aspect of student motivation that was not considered in the survey: "I have to tell you that my confidence level in public speaking (and eventually being a leader in any group) jumped TONS OF LEVELS from Presentation Idol. If you did not encourage me to participate in Presentation Idol, I cannot imagine myself being a leader in IEEE and any other groups."18 Winning Idol gave this student this confidence - and motivation - to pursue leadership roles he wouldn't have considered otherwise. For us as organizers of the event, this is the most rewarding outcome and the most persuasive evidence that $\mathrm{Idol}$ is effective in increasing student engagement.

While more research remains to be completed to understand the motivating factors for Idol participants, sharp percentage differences between the respondents in the pre- and postcommunication survey groups and the respondents in the pre- and post-Idol survey groups seems to indicate that the Idol participants are highly motivated by typical game characteristics like competition and reward.

\section{Directions for future research}


We are planning to conduct focus groups with targeted participants to corroborate the survey findings and to explore research questions about students' motivations beyond what we could learn from the surveys. We also hope to look more deeply at student engagement and especially the benefits of interdisciplinary interactions, competitions, and industry involvement. As well, we plan to survey Idol audience members, judges, industry supporters, and other participants about their experience of the event. Ideally, we'd like other engineering schools to be able to develop similar competitions, perhaps leading to regional competitions between schools.

We see the value in measuring changes in presentation behaviour to identify ways participating in Idol helps students become better communicators. However, several factors restrict us from using one rubric for all presentation evaluations (both in Comm courses and in Idol). Among these are simplicity of presentation evaluation for our industry judges, instructor preferences, and the fact that our courses are tailored to the needs of each discipline. Also, Idol organizers want to be careful that the Idol event does not carry over to the student's regular communication class.

In terms of the future of Idol, we plan to add new presentation categories, such as team presentations, elevator pitches, Pecha Kucha or Ignite style presentations, and debating. Adding these categories would open up new areas to research as well as adding variety and excitement.

\section{References}

1. Canadian Engineering Accreditation Board. 2012. Accreditation Criteria and Procedures 2012. Retrieved from http://www.engineerscanada.ca/files/w_Accreditation_Criteria_Procedures_2012.pdf

2. ABET, Inc. (2011). Criteria for Accrediting Engineering Programs, 2012-2013. Retrieved from http://www.abet.org/DisplayTemplates/DocsHandbook.aspx?id=3143

3. National Academy of Engineering (NAE). (2005) . Educating the Engineer of 2020: Adapting Engineering Education in the New Century. Washington, DC: National Academies Press.

4. Donnell, J., Aller, B.M., Alley, M., Kedrowicz, A.A. (2011). Why industry says that engineering graduates have poor communication skills: What the literature says. ASEE Conference (session AC 2011-1503)

5. Mobrand, K, \& Turns, J.A., (2011). Revisiting communication experiences to prepare for professional practice, ASEE Conference (session AC 2011-2241)

6. Paretti, M.C. (2008). Teaching Communication in Capstone Design: The Role of the Instructor in Situated Learning. Journal of Engineering Education. Vol. 97, No. 4, pp. 491-503.

7. Peercy, P.S., Cramer, S.M. (2011). Redefining Quality in Engineering Education Through Hybrid Instruction. Journal of Engineering Education. Vol. 100, No. 4, pp. 625-629.

8. American Society for Engineering Education. 2012. Innovating with Impact: Creating a Culture for Scholarly and Systematic Innovation in Engineering Education. Washington, DC: American Society for Engineering Education. Retrieved from http://www.asee.org/about-us/the-organization/advisory-committees/Innovation-with-Impact

9. Otomo, K. (January 28, 2013). Personal Communication. 
10. Allendoerfer, Cheryl; Wilson, Denise; Bates, Rebecca; Crawford, Joy; Jones, Diane; Floyd-Smith, Tamara; Plett, Melani; Scott, Elaine; Veilleux, Nanette. (2012). Strategic Pathways for Success: The Influence of Outside Community on Academic Engagement. Journal of Engineering Education. Vol. 101 Issue 3, pp. 512-538.

11. Rodgers, K.A., Marra, R.M., Shen, D., Bogue, B. (2012). Leaving Engineering: A Multi-Year Single Institution Study. Journal of Engineering Education. Vol. 101, No. 1, pp. 6-27.

12. Klopfer, E., Osterweil, S., \& Salen, K. (2009). Moving learning games forward: Obstacles, opportunities, and openness. The education arcade. Retrieved from http://education.mit.edu/papers/MovingLearningGamesForward_EdArcade.pdf

13. Horizon Report 2011. (2011). Two to three years: Game-based learning. Retrieved from http://wp.nmc.org/horizon2011/sections/game-based-learning/

14. Henderson, D. (2005). Games: Making Learning Fun. In M.H. Oermann \& K. Heinrich (Eds.) Annual Review of Nursing Education (Vol 3. pp. 165-183). New York: Springer Publishing Company.

15. Trybus, J. (2012). Game-based learning: What it is, why it works, and where it’s going. Retrieved from http://www.newmedia.org/game-based-learning--what-it-is-why-it-works-and-where-its-going.html

16. Case, J.M., Light, G. (2011) Emerging Methodologies in Engineering Education Research. Journal of Engineering Education. Vol. 100, No. 1, pp. 186-210.

17. Norback \& Utschig Presentation Scoring System. Copyright ( Georgia Tech Research Corporation. V4.2 Sr Design 08/05/10. Contact jnorback@isye.gatech.edu or tris.utschig@cetl.gatech.edu

18. Moon, T.J. (December 10, 2012). Personal communication. 


\section{Appendix A: Norback \& Utschig Presentation Scoring System \\ Rubric for Engineering Student Presentations, Based on Executive Input Norback \& Utschig}

Rater

I. Customizing to the audience

${ }^{1}$ Audience

connection

2Appropriate

language

${ }^{3}$ Relevant details

${ }^{4}$ Taking questions
Course

$\begin{array}{ccccc}\text { No } & \begin{array}{l}\text { Not } \\ \text { much }\end{array} & \begin{array}{c}\text { Yes, } \\ \text { but }\end{array} & \text { Yes } & \text { Wow! } \\ 1 & 2 & 3 & 4 & 5 \\ 1 & 2 & 3 & 4 & 5 \\ 1 & 2 & 3 & 4 & 5 \\ 1 & 2 & 3 & 4 & 5\end{array}$

Date

Audience member characteristics are identified ahead of the presentation as observed through presentation details tailored to audience interests and needs

Refers directly to audience needs to help define purpose/goals of presentation

Describes concepts at just the right level for particular audience

Uses concrete examples and details familiar to audience

Adeptly accepts and satisfactorily answers audience questions

Comments:

\section{Telling the} story

5equencing

Key points

${ }^{7}$ Context

${ }^{8}$ Sensitivity to time
No much but Yes Wow!

$\begin{array}{lllll}1 & 2 & 3 & 4 & 5\end{array}$

$\begin{array}{lllll}1 & 2 & 3 & 4 & 5\end{array}$

$\begin{array}{lllll}1 & 2 & 3 & 4 & 5\end{array}$

$\begin{array}{lllll}1 & 2 & 3 & 4 & 5\end{array}$
Displays a logical flow and interconnectedness of the different parts of the presentation to create a memorable, unified message

Links different parts of the presentation and uses appropriate transitions

Consistently refers to how key points fit into the big picture

Clearly illustrates major points by linking to additional relevant information

Begins/ends on time even with questions throughout presentation

Comments:

\section{Displaying key} information

${ }^{9}$ Layout and design

${ }^{10}$ Focused content

${ }^{11}$ Amount of text

${ }^{12}$ Appropriate

graphics

${ }^{13}$ Engaging graphics
No

Not Yes, much but Yes Wow!

$\begin{array}{lllll}1 & 2 & 3 & 4 & 5\end{array}$

$12 \quad 3 \quad 4 \quad 5$

$\begin{array}{lllll}1 & 2 & 3 & 4 & 5\end{array}$

$\begin{array}{lllll}1 & 2 & 3 & 4 & 5\end{array}$

$\begin{array}{lllll}1 & 2 & 3 & 4 & 5\end{array}$
Graphics and written information enhance and reinforce the oral delivery through a focus on key points and helpful supporting information

Information is easily understood due to layout and color is used appropriately

For each slide, information supports only one or two key points

Uses an appropriate amount of text to describe essence of key point(s)

Maps/charts/graphs/pictures/illustrations used clearly support key points Graphics are visually appealing, easy to understand, include helpful labeling

Comments: 
IV. Delivering the presentation

${ }^{14} \mathrm{First} /$ last

impression

${ }^{15}$ Flow

${ }^{16}$ Elaboration

${ }^{17}$ Stature

${ }^{18}$ Vocal quality

${ }^{19}$ Personal presence
Not Yes, No much but Yes Wow!

$\begin{array}{lllll}1 & 2 & 3 & 4 & 5\end{array}$

$12 \quad 3 \quad 4 \quad 5$

$\begin{array}{lllll}1 & 2 & 3 & 4 & 5\end{array}$

$\begin{array}{lllll}1 & 2 & 3 & 4 & 5\end{array}$

$\begin{array}{lllll}1 & 2 & 3 & 4 & 5\end{array}$

$\begin{array}{lllll}1 & 2 & 3 & 4 & 5\end{array}$

Uses both verbal and nonverbal skills to enhance the delivery of the presenter's message

5 Grabs audience attention at beginning and inspires them with the closing Knows material well without memorization or repeated hesitations, ums, etc.

Avoids reading slides and instead elaborates on slide content

Uses good posture and bearing

Adapts tone, volume and pace to emphasize key points

Effectively combines energy, inflection, eye contact, and movement

Comments:

Norback \& Utschig Presentation Scoring System. Copyright (C Georgia Tech Research Corporation. V4.2 Sr Design 08/05/10. Non-commercial use is approved without further pel commercial use is allowed without written permission of the Georgia Tech Research Corporation, Atlanta, Georgia 30332. For questions, contact jnorback@isye.gatech.edu or tris.utschig@cetl.gatech.edu 


\section{Appendix B: Pre- and post-communication presentation survey}

(The questionnaire was delivered online. The same questionnaire was administered before and after students gave presentations in their Communication class.)

1. What engineering discipline are you studying? (Check one)

\begin{tabular}{|l|l|}
\hline Civil & \\
\hline Electrical \& Computer & \\
\hline Mechanical & \\
\hline
\end{tabular}

2. Is this your first technical communication course?

\begin{tabular}{|l|l|}
\hline Yes & \\
\hline No & \\
\hline
\end{tabular}

3. Gender

\begin{tabular}{|l|l|}
\hline Male & \\
\hline Female & \\
\hline Undisclosed & \\
\hline Other & \\
\hline
\end{tabular}

4. Age

\begin{tabular}{|l|l|}
\hline $16-19$ & \\
\hline $20-25$ & \\
\hline $25-30$ & \\
\hline $30-35$ & \\
\hline $35-40$ & \\
\hline $40+$ & \\
\hline
\end{tabular}

5. What is your previous education?

\begin{tabular}{|l|l|}
\hline Completed high school or GED & \\
\hline Completed some post-secondary & \\
\hline Completed a post-secondary certificate or diploma & \\
\hline Completed an undergraduate degree & \\
\hline Completed some graduate work & \\
\hline Completed a graduate degree & \\
\hline
\end{tabular}

6. How many years of full-time work experience do you have?

\begin{tabular}{|l|l|}
\hline 0 & \\
\hline $1-2$ & \\
\hline $2-5$ & \\
\hline $5-10$ & \\
\hline $10+$ & \\
\hline
\end{tabular}

7. The following three questions are about how much experience you have giving presentations/public speaking for work, for school, and for volunteer/other organizations.

a. How much experience do you have giving presentations/public speaking for work?(check as many as apply)

\begin{tabular}{|l|l|l|l|l|l|l|}
\hline Audience Size & \multicolumn{6}{|l|}{ Number of Presentations } \\
\hline & 0 & $1-5$ & $6-10$ & $10-20$ & $20-50$ & $50+$ \\
\hline $1-5$ people & & & & & & \\
\hline $6-10$ people & & & & & & \\
\hline $10-20$ people & & & & & & \\
\hline 20-50 people & & & & & & \\
\hline $50-100$ people & & & & & & \\
\hline
\end{tabular}




\begin{tabular}{|l|l|l|l|l|l|l|}
\hline $100+$ people & & & & & & \\
\hline
\end{tabular}

b. How much experience do you have giving presentations/public speaking for school?(check as many as apply)

\begin{tabular}{|l|l|l|l|l|l|l|}
\hline Audience Size & \multicolumn{6}{|l|}{ Number of Presentations } \\
\hline & 0 & $1-5$ & $6-10$ & $10-20$ & $20-50$ & $50+$ \\
\hline $1-5$ people & & & & & & \\
\hline $6-10$ people & & & & & & \\
\hline $10-20$ people & & & & & & \\
\hline $20-50$ people & & & & & & \\
\hline $50-100$ people & & & & & & \\
\hline $100+$ people & & & & & & \\
\hline
\end{tabular}

c. How much experience do you have giving presentations/public speaking for volunteer/other organizations?(check as many as apply)

\begin{tabular}{|l|l|l|l|l|l|l|}
\hline Audience Size & \multicolumn{6}{|c|}{ Number of Presentations } \\
\hline & 0 & $1-5$ & $6-10$ & $10-20$ & $20-50$ & $50+$ \\
\hline $1-5$ people & & & & & & \\
\hline $6-10$ people & & & & & & \\
\hline $10-20$ people & & & & & & \\
\hline $20-50$ people & & & & & & \\
\hline $50-100$ people & & & & & & \\
\hline 100 + people & & & & & & \\
\hline
\end{tabular}

8. On a scale of 1 to 5 , where 1 represents "no nervous feelings at all” and 5 represents "extremely nervous", rate your feelings of nervousness prior to delivering an oral presentation.

\begin{tabular}{|l|l|l|l|l|}
\hline 1 & 2 & 3 & 4 & 5 \\
\hline & & & & \\
\hline
\end{tabular}

9. Would the competitive nature of Presentation Idol motivate you to participate?

\begin{tabular}{|l|l|}
\hline Yes & \\
\hline No & \\
\hline
\end{tabular}

10. Would the chance of winning prize money motivate you to participate in Presentation Idol?

\begin{tabular}{|l|l|}
\hline Yes & \\
\hline No & \\
\hline
\end{tabular}

11. Do you feel that giving oral presentations or talking about your work is an important part of an engineering career?

\begin{tabular}{|l|l|}
\hline Yes & \\
\hline No & \\
\hline Unsure & \\
\hline
\end{tabular}




\section{Appendix C: Pre- and Post-Idol surveys}

These surveys were delivered online in TWO PARTS: one questionnaire was available before Idol and another after Idol)

\section{Part ONE—Questions for Participants Before Idol}

12. What engineering discipline are you studying? (Check one)

\begin{tabular}{|l|l|l|l|l|}
\hline & Diploma & Degree & Undecided & Other \\
\hline Civil & & & & \\
\hline Electrical \& Computer & & & & \\
\hline Mechanical & & & & \\
\hline Architectural \& Building & & & & \\
\hline Biomedical & & & & \\
\hline Environmental & & & & \\
\hline Other & & & & \\
\hline
\end{tabular}

If 'other', please specify:

13. Is this your first time participating in Idol? (Check one)

\begin{tabular}{|l|l|}
\hline Yes & \\
\hline No & \\
\hline
\end{tabular}

14. Gender (Check one)

\begin{tabular}{|l|l|}
\hline Male & \\
\hline Female & \\
\hline Undisclosed & \\
\hline Other & \\
\hline
\end{tabular}

15. Age (Check one)

\begin{tabular}{|l|l|}
\hline $16-19$ & \\
\hline $20-25$ & \\
\hline $25-30$ & \\
\hline $30-35$ & \\
\hline $35-40$ & \\
\hline $40+$ & \\
\hline
\end{tabular}

16. What is your previous education?

Completed high school or GED

Completed some post-secondary

Completed a post-secondary certificate or diploma

Completed an undergraduate degree

Completed some graduate work

Completed a graduate degree

17. How many years of full-time work experience do you have?

\begin{tabular}{|l|l|}
\hline 0 & \\
\hline $1-2$ & \\
\hline $2-5$ & \\
\hline $5-10$ & \\
\hline $10+$ & \\
\hline
\end{tabular}


18. The following three questions are about how much experience you have giving presentations/public speaking for work, for school, and for volunteer/other organizations.

a. How much experience do you have giving presentations/public speaking for work? (check as many as apply)

\begin{tabular}{|l|l|l|l|l|l|l|}
\hline Audience Size & \multicolumn{6}{|l|}{ Number of Presentations } \\
\hline & 0 & $1-5$ & $6-10$ & $10-20$ & $20-50$ & $50+$ \\
\hline $1-5$ people & & & & & & \\
\hline $6-10$ people & & & & & & \\
\hline $10-20$ people & & & & & & \\
\hline $20-50$ people & & & & & & \\
\hline $50-100$ people & & & & & & \\
\hline $100+$ people & & & & & & \\
\hline
\end{tabular}

b. How much experience do you have giving presentations/public speaking for school? (check as many as apply)

\begin{tabular}{|l|l|l|l|l|l|l|}
\hline Audience Size & \multicolumn{6}{|l|}{ Number of Presentations } \\
\hline & 0 & $1-5$ & $6-10$ & $10-20$ & $20-50$ & $50+$ \\
\hline $1-5$ people & & & & & & \\
\hline $6-10$ people & & & & & & \\
\hline $10-20$ people & & & & & & \\
\hline $20-50$ people & & & & & & \\
\hline $50-100$ people & & & & & & \\
\hline $100+$ people & & & & & & \\
\hline
\end{tabular}

c. How much experience do you have giving presentations/public speaking for volunteer/other organizations? (check as many as apply)

\begin{tabular}{|l|l|l|l|l|l|l|}
\hline Audience Size & \multicolumn{6}{|l|}{ Number of Presentations } \\
\hline & 0 & $1-5$ & $6-10$ & $10-20$ & $20-50$ & $50+$ \\
\hline $1-5$ people & & & & & & \\
\hline $6-10$ people & & & & & & \\
\hline $10-20$ people & & & & & & \\
\hline $20-50$ people & & & & & & \\
\hline $50-100$ people & & & & & & \\
\hline $100+$ people & & & & & & \\
\hline
\end{tabular}

19. On a scale of 1 to 5 , where 1 represents "no nervous feelings at all” and 5 represents "extremely nervous", rate your feelings of nervousness prior to delivering an oral presentation.

\begin{tabular}{|l|l|l|l|l|}
\hline 1 & 2 & 3 & 4 & 5 \\
\hline & & & & \\
\hline
\end{tabular}

20. Does the chance of presenting in a competitive situation with your peers motivate you to participate in Idol?

\begin{tabular}{|l|l|}
\hline Yes & \\
\hline No & \\
\hline
\end{tabular}

21. Does the chance of winning prize money in a competitive situation motivate you to participate in Idol?

\begin{tabular}{|l|l|}
\hline Yes & \\
\hline No & \\
\hline
\end{tabular}


22. Do you feel that giving oral presentations or talking about your work is an important part of an engineering career?

\begin{tabular}{|l|l|}
\hline Yes & \\
\hline No & \\
\hline Unsure & \\
\hline
\end{tabular}

\section{Part TWO-Questions for Participants After Idol}

1. What engineering discipline are you studying? (Check one)

\begin{tabular}{|l|l|l|l|l|}
\hline \multicolumn{1}{|c|}{ 2. } & Diploma & Degree & Undecided & Other \\
\hline Civil & & & & \\
\hline Electrical \& Computer & & & & \\
\hline Mechanical & & & & \\
\hline Architectural \& Building & & & & \\
\hline Biomedical & & & & \\
\hline Environmental & & & & \\
\hline Other & & & & \\
\hline
\end{tabular}

If 'other', please specify:

3. Was this your first time participating in Idol?

\begin{tabular}{|l|l|}
\hline Yes & \\
\hline No & \\
\hline
\end{tabular}

4. Gender

\begin{tabular}{|l|l|}
\hline Male & \\
\hline Female & \\
\hline Undisclosed & \\
\hline Other & \\
\hline
\end{tabular}

5. Age

\begin{tabular}{|l|l|}
\hline $16-19$ & \\
\hline $20-25$ & \\
\hline $25-30$ & \\
\hline $30-35$ & \\
\hline $35-40$ & \\
\hline $40+$ & \\
\hline
\end{tabular}

6. What is your previous education?

\begin{tabular}{|l|l|}
\hline Completed high school or GED & \\
\hline Completed some post-secondary & \\
\hline Completed a post-secondary certificate or diploma & \\
\hline Completed an undergraduate degree & \\
\hline Completed some graduate work & \\
\hline Completed a graduate degree & \\
\hline
\end{tabular}

7. How many years of full-time work experience do you have?

\begin{tabular}{|l|l|}
\hline 0 & \\
\hline $1-2$ & \\
\hline $2-5$ & \\
\hline $5-10$ & \\
\hline
\end{tabular}


8. The following three questions are about how much experience you have giving presentations/public speaking for work, for school, and for volunteer/other organizations.

a. How much experience do you have giving presentations/public speaking for work? (check as many as apply)

\begin{tabular}{|l|l|l|l|l|l|l|}
\hline Audience Size & \multicolumn{6}{|l|}{ Number of Presentations } \\
\hline & 0 & $1-5$ & $6-10$ & $10-20$ & $20-50$ & $50+$ \\
\hline $1-5$ people & & & & & & \\
\hline $6-10$ people & & & & & & \\
\hline $10-20$ people & & & & & & \\
\hline $20-50$ people & & & & & & \\
\hline $50-100$ people & & & & & & \\
\hline $100+$ people & & & & & & \\
\hline
\end{tabular}

b. How much experience do you have giving presentations/public speaking for school? (check as many as apply)

\begin{tabular}{|l|l|l|l|l|l|l|}
\hline Audience Size & \multicolumn{6}{|l|}{ Number of Presentations } \\
\hline & 0 & $1-5$ & $6-10$ & $10-20$ & $20-50$ & $50+$ \\
\hline $1-5$ people & & & & & & \\
\hline $6-10$ people & & & & & & \\
\hline $10-20$ people & & & & & & \\
\hline $20-50$ people & & & & & & \\
\hline $50-100$ people & & & & & & \\
\hline $100+$ people & & & & & & \\
\hline
\end{tabular}

c. How much experience do you have giving presentations/public speaking for volunteer/other organizations? (check as many as apply)

\begin{tabular}{|l|l|l|l|l|l|l|}
\hline Audience Size & \multicolumn{6}{|l|}{ Number of Presentations } \\
\hline & 0 & $1-5$ & $6-10$ & $10-20$ & $20-50$ & $50+$ \\
\hline $1-5$ people & & & & & & \\
\hline $6-10$ people & & & & & & \\
\hline $10-20$ people & & & & & & \\
\hline $20-50$ people & & & & & & \\
\hline $50-100$ people & & & & & & \\
\hline $100+$ people & & & & & & \\
\hline
\end{tabular}

9. On a scale of 1 to 5 , where 1 represents "no nervous feelings at all” and 5 represents "extremely nervous", rate your feelings of nervousness prior to delivering your Idol presentation.

\begin{tabular}{|l|l|l|l|l|}
\hline 1 & 2 & 3 & 4 & 5 \\
\hline & & & & \\
\hline
\end{tabular}

10. On a scale of 1 to 5 , where 1 represents "not at all" and 5 represents "very much", rate how much you feel the extra time and effort you spent to prepare and deliver your Idol presentation improved your ability or competency in delivering oral presentations generally.

\begin{tabular}{|l|l|l|l|l|}
\hline 1 & 2 & 3 & 4 & 5 \\
\hline & & & & \\
\hline
\end{tabular}

Can you explain why you feel this way? 
11. On a scale of 1 to 5 , where 1 represents "not motivating at all” and 5 represents "very motivating", rate how motivating was it for you to participate in Idol knowing that a substantial amount of prize money could potentially be won.

\begin{tabular}{|l|l|l|l|l|}
\hline 1 & 2 & 3 & 4 & 5 \\
\hline & & & & \\
\hline
\end{tabular}

12. On a scale of 1 to 5 , where 1 represents “extremely dissatisfied” and 5 represents “extremely satisfied”, rate your level of satisfaction with the following aspects of Idol:

\begin{tabular}{|c|c|c|c|c|c|c|}
\hline & 1 & 2 & 3 & 4 & 5 & N/A \\
\hline \multicolumn{7}{|l|}{ Advertising/Recruitment of participants } \\
\hline \multicolumn{7}{|l|}{ Registration } \\
\hline \multicolumn{7}{|l|}{ Communication around the events } \\
\hline \multicolumn{7}{|l|}{ Location of the preliminary rounds } \\
\hline \multicolumn{7}{|l|}{ Location of the championship round } \\
\hline \multicolumn{7}{|l|}{ Your performance } \\
\hline \multicolumn{7}{|l|}{ Judging of the preliminary rounds } \\
\hline \multicolumn{7}{|l|}{ Judging of the championship rounds } \\
\hline \multicolumn{7}{|l|}{ Value of the Judges' Choice prizes } \\
\hline \multicolumn{7}{|l|}{ Value of the People’s Choice prizes } \\
\hline \multicolumn{7}{|l|}{ Quality and variety of refreshments at the championship round } \\
\hline \multicolumn{7}{|l|}{ Social aspects (networking, debriefing etc) } \\
\hline \multicolumn{7}{|l|}{$\begin{array}{l}\text { Opportunity to meet engineers/engineering students from other } \\
\text { disciplines }\end{array}$} \\
\hline Overall organization of the events & & & & & & \\
\hline
\end{tabular}

Do you have any comments on any of the aspects of the competition?

13. On a scale of 1 to 5, where 1 represents "not much" and 5 represents "significantly", rate how valuable was it for you to give your presentation to an engineering audience from various disciplines.

\begin{tabular}{|l|l|l|l|l|}
\hline 1 & 2 & 3 & 4 & 5 \\
\hline & & & & \\
\hline
\end{tabular}

14. On a scale of 1 to 5, where 1 represents "not much" and 5 represents "significantly", rate how valuable was it for you to be judged on your presentation by someone other than a Communication instructor.

\begin{tabular}{|l|l|l|l|l|}
\hline 1 & 2 & 3 & 4 & 5 \\
\hline & & & & \\
\hline
\end{tabular}

15. Did you work collaboratively to prepare your Idol presentation? For example, did you practice your presentation in front of others and get their feedback?

\begin{tabular}{|l|l|}
\hline Yes & \\
\hline No & \\
\hline
\end{tabular}

16. If you answered yes to questions 15, with how many people and from which areas?

17. On a scale of 1 to 5, where 1 represents "not much" and 5 represents "significantly", rate how much you 
feel participating in Idol has improved your ability to deliver a presentation.

\begin{tabular}{|l|l|l|l|l|}
\hline 1 & 2 & 3 & 4 & 5 \\
\hline & & & & \\
\hline
\end{tabular}

18. On a scale of 1 to 5 , where 1 represents "not much" and 5 represents "significantly", rate how much you feel participating in Idol has improved your confidence in delivering a presentation.

\begin{tabular}{|l|l|l|l|l|}
\hline 1 & 2 & 3 & 4 & 5 \\
\hline & & & & \\
\hline
\end{tabular}

19. What aspects of participating in Idol helped you improve your presentation skills?

20. Is the experience of delivering a presentation in Presentation Idol more memorable than delivering a presentation in a communication class at BCIT? At work?

\begin{tabular}{|l|l|l|}
\hline & At BCIT & At work \\
\hline Yes & & \\
\hline No & & \\
\hline
\end{tabular}

Please explain your answer.

21. Do you think the experience of delivering a presentation in Presentation Idol is more representative of presenting in the 'real world' than in a typical class?

\begin{tabular}{|l|l|}
\hline Yes & \\
\hline No & \\
\hline
\end{tabular}

Please explain your answer.

22. Did participating in Idol motivate you to use new and innovative methods or strategies for success (as opposed to what you may have done in previous communication courses at BCIT or at work)?

\begin{tabular}{|l|l|}
\hline Yes & \\
\hline No & \\
\hline
\end{tabular}

What were they?

23. Is there anything else you'd like to tell us? 